\title{
PTPRC Gene
}

National Cancer Institute

\section{Source}

National Cancer Institute. PTPRC Gene. NCI Thesaurus. Code C24711.

This gene plays a role in suppression of cytokine receptor signaling and the regulation of signal transduction in lymphocytes. 